\title{
Hidden costs of cuts: Austerity, civil service management and the motivation of public officials in Central and Eastern Europe after the crisis
}

\author{
Jan-Hinrik Meyer-Sahling, University of Nottingham \\ Barbara Janta, RAND Europe \\ Iveta Reinholde, University of Latvia \\ Christian van Stolk, RAND Europe
}

\begin{abstract}
The implementation of austerity measures presents a dilemma for governments. While austerity measures such as cutbacks aim to reduce costs and enhance public sector efficiency, the same measures might undermine the motivation of employees and, consequently, the prospects of effectively implementing austerity programmes. Based on a survey of ministerial officials in Poland and Latvia, this article finds that the scale of cutbacks explains a larger decline of staff motivation in Latvia than in Poland. The article further shows that motivation was more likely to decrease after the crisis if austerity measures involved cutbacks such as staff reductions, recruitment freezes, and a reduction of training opportunities.
\end{abstract}

\section{Keywords}

Economic crisis; austerity; cutbacks; civil service reform; motivation; Central and Eastern Europe.

\section{JEL classification}

H50; J30; D73. 


\section{Introduction}

The global financial crisis has provoked a new debate over the status and contribution of public administration research in the age of austerity (Kelly and Dodds 2012; Lodge and Wegrich 2012; Potter 2012). At the macro-level, research has concentrated on the vulnerability of the state in member states of the Organisation for Economic Co-operation and Development (OECD) (Lodge and Hood 2012), the type of responses that governments have selected to tackle the crisis (Armingeon 2012), and the political and economic determinants of fiscal consolidation (Lodge and Rodríguez-Vives 2013; Kickert et al 2015). With regard to the organisation of public administration, research has explored the impact of the crisis on administrative reform (Randma-Liiv and Kickert 2016), decision-making and coordination in public administration (Peters et al 2011; Savi/Randma-Liiv 2015), human resources management practices (Parrado 2010; Demmke 2016), compensation packages (OECD 2012) and leadership competencies (Leslie and Canwell 2010; Lodge and Hood 2012).

Much less is still known about the position of public officials vis-à-vis the economic crisis and the austerity measures that have since been passed to varying extent in European democracies. This is especially true for the motivation of public officials after the crisis. The motivation of employees is widely recognised as a key determinant of organisational performance in the public and private sector (Huselid 1995; Hondeghem and Perry 2009; Brewer and Brewer 2011). The motivation of officials and hence their willingness to exert effort is therefore an important condition for the successful implementation of austerity programmes.

However, governments that seek to implement austerity programmes face a dilemma, in that public officials are simultaneously agents and objects of reform. On the one hand, austerity measures such as cutbacks, which are the focus of this article, tend to be associated with staff reductions, wage and pension cuts, hiring and promotion freezes, and fewer resources for training and development (see, for instance, Parrado 2010; UNDP 2010; OECD 2012; Raudla et al 2015; Demmke 2016). Austerity measures might therefore involve hidden costs, in that they have an inherently de-motivating effect on public officials. At the same time, governments have to rely on public officials to implement austerity measures that target public administration and public policy programmes. In the worst case, the efficiency gains from austerity measures are offset by motivational losses trapping government in a vicious circle cutting costs and motivation at the same time.

This article addresses this dilemma. It builds on the literature on human resource management, motivation and performance in the public and private sector to examine the impact of post-crisis cutbacks in the area of civil service management on the motivation of public officials. The article focuses on the impact of human resource management practices that follow the enactment of cutback measures. It examines five areas of civil service management including post-crisis changes in recruitment, promotion, dismissal, salary management and training policy in order to identify which of these areas have had an effect on the motivation of officials. In addition, the article assesses the extent to which the wider context such as the scale of a country's austerity programme and the type of ministry as the immediate work context affect the motivation of officials.

Empirically, the article is based on a survey of ministerial officials in two countries from Central and Eastern Europe: Latvia and Poland. Latvia belongs the group of European countries that was hardest hit by the global financial crisis. Latvia had to apply for support from the International Monetary Fund (IMF) and the European Commission in order to avoid default. The international loans were followed by a large-scale restructuring of the public sector including major cutbacks in the civil service. Poland, by contrast, is among the European Union (EU) member states that was least affected by the crisis insofar as growth of gross domestic product (GDP) remained positive during the post-crisis period. Consequently, public sector 
restructuring efforts have been far more moderate. The comparison of Poland and Latvia therefore provides an opportunity to disentangle the impact of country-level austerity measures and individual-level experience of changing management practices on the motivation of public officials after the global financial crisis hit these two countries.

The analysis shows that Latvian officials perceive a much larger decline of motivation than Polish officials. This difference is likely to reflect the scale of cutback measures in Latvia. At the same time, no effect is found within countries for officials who work in finance and economics ministries. With regard to differences between areas of civil service management, the analysis reveals that motivation among ministerial officials was likely to decrease if they experienced hiring freezes, staff cuts and a reduction of training opportunities. By contrast, promotion freezes and salary cuts are not found to have a consistent effect on the motivation of officials.

\section{Austerity and motivation: What to expect for public officials after the crisis}

The motivation of employees is an important determinant of organisational performance in the public and private sector (Huselid 1995; Guest 1997; Hondeghem and Perry 2009; Brewer and Brewer 2011). Most generally, motivation refers to a personal disposition, a psychological trait to act towards a desired goal. It is typically associated with the willingness to exert effort. In human resource management, motivation is widely regarded as a critical outcome of human resource management practices and one of the key mechanisms to generate firm performance (Rainey 2001). More specifically, it 'consists of an individual's direction, intensity, and duration of effort. Motivation manifests itself in the individual's choices to exert effort, choices of how much effort to exert, and choices of how long to exert the effort' (Lepak et al 2006: 232). ${ }^{16}$

Research on human resource management has paid particular attention to the impact of human resource management strategies and practices on organizational performance. Approaches differ with regard to the scope of management practices that they examine and the type of performance outcome they seek to observe (Wright and Boswell 2002). Broad, inclusive perspectives assess the impact of human resource management systems, that is, a combination of human resource management functions and their relation to performance (Huselid 1995). By contrast, narrow approaches focus on individual management practices, for instance, the impact of incentive pay schemes on performance in public and private sector organisations (Marsden 2010; Dahlstroem and Lapuente 2010). Second, performance outcomes are either observed at the level of organisations or at the level of individuals. The former focuses on indicators such as the financial performance of firms. By contrast, at the individual level studies examine the job satisfaction, commitment, turnover and personal health and wellbeing.

The fourfold distinction of approaches to the study of human resource management and organizational performance provides a helpful foundation for assessing the impact of austerity measures on the motivation of public officials,

\footnotetext{
${ }^{16}$ The difficulty to define motivation or more specifically 'work motivation', which focuses on work-related behaviour, is widely recognised (Rainey 2001, Wright 2001). Yet definitions tend to find common ground in their focus on effort exerted by the employee and the reference to intensity, direction and persistence/duration of effort. Note also that our understanding of motivation differs from the notion of 'public service motivation'. The latter is a specific type of motivation defined as 'an individual predisposition to respond to motives grounded primarily or uniquely in public institutions' (Perry/Wise 1990: 368, see Hondeghem/Perry 2009 for a recent review). However, the insights of this body of literature are relevant for the present article and will be referred to below.
} 
which is the focus of this article. First, among austerity measures we focus on cutback measures in relation to civil service management. Cutbacks in the area of civil service management primarily fall into the category of reducing operational expenditure (Raudla et al 2015). In this article, we focus on five areas of human resources management, including austerity-driven changes in recruitment, promotion, dismissal, salary management and training (see Demmke 2016 for a similar approach). We develop hypotheses for each of these human resource management functions and assess the relation to individual perceptions of motivation. Second, the research on work motivation in the public and private sector directs attention at other factors that might affect change in the context of austerity. For this study, we will later control for basic contextual parameters such as the severity of cutback measures in a given country and the position of finance and economics ministries within each country.

\section{Hiring freezes}

Recruitment policy refers here to the process of hiring new staff. This may involve the expansion of an organisation following the creation of new positions or simply the replacement of staff who have departed and hence the filling of vacancies. In the context of austerity, hiring freezes have been the main change in the area of recruitment policy (Parrado 2010; UNDP 2010; Demmke 2016). Governments have stopped to expand the civil service and they have stopped to replace staff and hence to fill vacancies. Hiring freezes may be associated with a cut of positions, while vacancies are simply maintained for a definite or indefinite time in others.

For existing staff, hiring freezes should not directly affect their motivation. After all, these officials do already have a job in the civil service and they do no longer have to compete for a position. However, hiring freezes have an indirect effect in that they affect the workload of officials. If vacancies are not filled, the remaining officials will have to cover and hence do a fair bit of extra work. As a result, hiring freezes have been argued to have negative effects on the job satisfaction of officials (Demmke 2016). We should therefore expect that hiring freezes are associated with a decline of motivation among public officials.

H1: The motivation of public officials is more likely to decrease if post-crisis recruitment policy has changed including hiring freezes (Recruitment hypothesis).

\section{Staff cuts}

Dismissal policy refers here to the process of firing officials from the civil service. Generally, it might include transfers and relocations in the civil service, but dismissals are clearly the most serious of these options in that they involve a termination of the public service relationship. In the context of austerity, dismissal policy plays a very important role for government. Mass work force cuts, quotas to reduce the number of staff, early retirement plans, the abolition of positions and terminations in the wake of administrative re-organisations are key instruments for governments to reduce fiscal costs and enhance the efficiency of public administration (Lodge and Hood 2012; Raudla et al 2015).

For public officials, a change in dismissal policy might not have a direct effect on their motivation at work. However, it has considerable threat potential and might undermine staff morale, as officials might fear to lose their job in the future. Moreover, it may be associated with higher workload comparable to the impact of hiring freezes because the same amount of work will have to be done by fewer people. We should therefore expect a negative effect of staff cuts on the motivation of public officials. 
H2: The motivation of public officials is more likely to decrease if post-crisis dismissal policy has changed including an increase in workforce cuts (Dismissal hypothesis).

\section{Promotion freezes}

Promotion policy refers to the upward mobility and career advancement of officials within an organisation. It might involve automatic promotions, competitions and simply nominations to higher ranks and positions. Promotions are usually associated with higher salary levels and hence tend to have direct effect on the reward levels of officials. In the context of austerity, promotion policy might simply lead to a freeze for upward mobility comparable to hiring freezes. Vacant positions at the higher level might also be kept open or they might even be cut, as a result of which promotion prospects narrow for officials in lower ranks.

For public officials a change in promotion policy should have a direct effect on their motivation, as it reduces opportunities for career advancement and salary increases. In rationalist terms, there are fewer incentives to work hard because there will be no reward. In addition, it might affect the motivation of officials because opportunities for the recognition of good performance and contributions to the organisation are no longer available. We should therefore expect that postcrisis promotion freezes should have a negative effect on the motivation of officials.

H3: The motivation of public officials is more likely to decrease if post-crisis promotion policy has changed including a narrowing of promotion opportunities (Promotion hypothesis).

\section{Salary cuts}

Salary policy is primarily concerned with the monetary compensation of officials. In remuneration terms this includes typically a fixed salary plus discretionary and nondiscretionary salary elements. The former include performance bonuses of various kinds, while the latter refers to rank-specific supplements, age-related supplements etc. In addition, one might consider non-monetary rewards and rewards that are paid after the end of the public service relations, in particular, pensions in this category (Brans and Peters 2012).

In the context of cutbacks, most elements of salary management tend to be affected (Demmke 2016). Fixed salaries might be frozen or even reduced. Similarly, bonuses might be frozen or cut. Non-monetary rewards also tend to be on the chopping board during periods of crisis. Public sector pensions are among the key areas in which governments aim to make savings, not less because the cuts in reward levels are not immediately felt by public officials.

For public officials, a change in salary policy should have a direct effect on their motivation (Guthrie 2008). Salary cuts, in particular, undermine the material incentives for public officials to work hard. Bonus cuts, pension cuts etc should have the same kind of effect. To be sure, public officials might be happy to have a job at all when considering that unemployment might go up in the private sector. Yet compared to the pre-crisis period, public officials are still experiencing a lower level of compensation for the same or even a higher level of workload. We therefore expect that austerity-driven changes in salary policy are associated with a decrease in motivation among public officials.

H4: The motivation of public officials is more likely to decrease if post-crisis salary policy has changed including salary cuts (Salary hypothesis).

\section{Cutting training opportunities}

Training policy refers here to the development of skills and competencies of public officials in the context of their employment relation. It differs from pre-service 
training such as university education. In-service training can take a large number of forms such as short and long courses funded and provided by ministries and agencies, national schools and institute for the training of officials, universities, international organisations and the private sector. It might also include support for university study at home and abroad, exchanges and increasingly online education.

Cutback measures in the area of training policy most naturally involve the reduction in the provision of training opportunities (Metsma 2014). This may range from a reduction of budgetary resources to the closure of public training institutes. Moreover, training budgets tend to be soft budgets in the sense that governments find it less difficult to cut funding in this area during a period of crisis (Demmke 2016).

For public officials, we should expect that a cut in the provision of training opportunities lowers the motivation of officials. Training provides an opportunity to develop skills and hence to perform well on the job. Participation in training courses also tends to provide an incentive for staff, in particular, when it involves travel abroad or the acquisition of higher-level qualifications such as via study abroad programmes. We therefore expect cutbacks in the area of training policy after the crisis to have a negative effect on the motivation of officials.

H5: The motivation of public officials is more likely to decrease if post-crisis training policy has changed including a reduction in training opportunities (Training hypothesis).

\section{Post-crisis civil service reforms in Latvia and Poland}

The analysis is based on a survey of ministerial officials that was conducted in 2010/2011 in Latvia and Poland. Latvia and Poland are two new member states from post-communist Central and Eastern Europe that joined the EU in 2004. With regard to the impact of the global economic crisis, the two countries differ significantly (Bideleux 2011). Latvia belongs to the EU members that was hardest hit by the crisis, while Poland belongs to the member states that was least affected. In Latvia, in 2009 economic output declined by 17.7 per cent, the highest slump in economic growth in the EU. The government deficit rose to 9.8 of GDP in and unemployment went from 6.5 per cent in 2007 to 18.2 per cent in 2009 and 19.8 per cent in 2010. ${ }^{17}$

In the winter of 2008/2009, Latvia asked the IMF and the EU for financial support in order to avoid default following the nationalisation of the Latvian bank Parex. The international loans were linked to a clear commitment from the Latvian government to reform its public finance by means of fiscal measures, social welfare reform, economic restructuring and specific measures for the reform of the financial sector. The programme for Economic Stabilisation and Growth included specific measures to reform public administration by means of reorganisation and expenditure cuts (Government of Latvia 2008).

In the context of the so-called Optimisation Plan for the reform of public administration, the government passed a range of civil service reform measures most of which aimed to cut operational expenditures. They included:

- Staff cuts by over 10 per cent (25.000 out of 205.000 officials were to be cut) primarily in the context of the re-organisation of public administration (Leta 2009).

\footnotetext{
17 For growth and unemployment figures, please see the official Eurostat figures available at http://epp.eurostat.ec.europa.eu/portal/page/portal/eurostat/home.
} 
- The government did not take an explicit decision on recruitment. However, due to need to downsize staff, it became impossible for ministries and agencies to hire new staff.

- Promotion freezes and formal downgrades in the context of the structural reorganisation of ministries and agencies in many ministries, while other ministries chose to dismiss officials. For heads of units, for instance, this meant that over a short period of time they became so-called senior officers and, as a result, lost their managerial attributes. Promotions were not formally frozen but in practice they took no longer place.

- Salary cuts by 15 per cent in January 2009 and again by around 20 per cent for top and middle staff in June 2009. Managers were given discretion to decide whether they would prefer to cut salaries at the top or mid-level. This led to considerable differences in the way salary cuts were experienced by civil servants (Memorandum 2009; Darzina 2009).

- The central government cut the funding for training institutions and training activities. The Latvian School of Public Administration lost 99 per cent of its funding (LSPA 2011). Training had to be paid for by ministries, agencies or personally by civil servants, leading to a major decline in training activities.

In contrast to Latvia, Poland experienced a softer landing after the global financial crisis hit Europe (Bideleux 2011). Economic growth remained positive for the entire post-crisis period reaching a low point of 1.6 per cent of GDP in 2009 but accumulating 17 per cent during the period from 2008 to 2012; the highest growth rate among EU member states. In 2008 and 2009, the unemployment rate varied between 7 and 9 per cent and until the end of 2012 it never rose above 10.5 per cent. Despite these positive figures, Poland experienced a high government deficit of 7.4 per cent of GDP in 2009 and public debt has continuously risen since the beginning of the global economic crisis towards its constitutional limit (see Rae 2013).

Given the far more moderate impact of the global economic crisis, the government of Poland did not embark on any major public administration reform. The Civil Service Law was amended in November 2008 but the change was not related to the looming crisis in the region. Yet several measures were still taken to address the changing context of public administration.

- The area of recruitment was affected in two ways. On the one hand, Bida (2009) argues that the number of vacancies that was publicly advertised increased. Moreover, he argues that both the number and quality of applicants per post increased compared to the pre-crisis period. On the other hand, the government reduced the quota of civil servants who were given the status of 'nominated civil servant', Poland differs from other countries in Central and Eastern Europe in that it distinguishes 'nominated civil servants' and 'civil service employees', The former have to undergo a lengthy recruitment and selection procedure, a preparatory service, they enjoy full tenure and significantly higher salary levels. Currently, just under 5 per cent of all civil servants (6.000 out of 122.000) are 'nominated civil servants', Initially the government aimed to raise this proportion to 10 per cent of all civil servants. However, in the context of austerity the government admitted a declining proportion of candidates who had successfully passed the nomination exam and even reduced the quota for new nominations to merely 200 in 2013 and 2014 (Gazeta Prawna 2011). 
- The government did not establish specific targets to reduce the staff numbers in central government ministries and agencies. Measures were taken to facilitate dismissals by means of disciplinary proceedings that were brought in line with the Labour Code but no efforts were made to downsize the civil service.

- The government did not pass specific measures to reduce promotion prospects for civil servants. However, following lengthy discussion the government decided that nominated civil servants would not be granted an automatic promotion if they pass two performance reviews successfully. This measure can be considered as a way of narrowing the promotion prospects for higher and senior civil servants (Gazeta Prawna 2013a).

- In the area of salary management, the government reviewed the salary bands shortly after the economic crisis emerged (Zieliński 2009). Even if this measure required additional government funds for some ministries, it was also decided that civil service salaries would be frozen from 2008. Since then they have increased but below the level of inflation, implying real wage decline for civil servants (Gazeta Prawna 2013b).

- With regard to training policy the government reviewed the process of selecting training providers. At the same time, training provision for civil servants was maintained at similar levels compared to the pre-crisis period.

The comparison of austerity-driven civil service reform strategies in the two countries suggests that human resource management practices were likely to change to a much larger extent in Latvia than in Poland. Yet in both cases, reforms are associated with a 'negative' development in that staff levels were cut, fewer officials were hired, promotion prospects narrowed, salaries were frozen or even cut and the provision of training was reduced. We would expect these developments to be reflected in the survey results and we would certainly expect that the motivation of officials in Latvia decreased to a larger extent than in Poland.

\section{Data, operationalization and descriptive results}

The empirical analysis is based on a survey of public officials that was conducted in the winter of 2010/2011 in Latvia and in the spring of 2011 in Poland (see also Meyer-Sahling and Mikkelsen 2016). It targeted civil servants employed at central government ministries. The survey was conducted in local languages as an online survey. It generated 1520 responses, including 972 from Poland and 547 from Latvia. The reliance on a web-based survey implies that we had no perfect control over the population of respondents, that is, we do not know with certainty who precisely was invited to participate in the online survey and whether officials who were invited also had a chance to complete the survey.

In order to maximise the consistency of the data across the two countries, we applied the same sampling procedure. In a first step, personal meetings were arranged with senior officials from the Civil Service Department in Poland and the State Chancellery in Latvia in order to explain the nature and purpose of the survey. Next, we sent the survey link together with a detailed explanation to our partners at the central institutions who then distributed the link to the heads of personnel in the ministries. In Latvia, this role is performed by the State Secretary. In Poland, the Director General is responsible for personnel affairs. Heads of personnel then sent the survey link to all civil servants employed in the core structure of their ministry.

As to the representativeness of the sample, we were able to check it in Poland against the population of officials in civil service ranks. It suggests that our sample 
is reasonably representative. Men are slightly over-represented in the sample (42 per cent as opposed to 35 per cent in the Polish civil service) and - as one might expect when conducting a web-based survey - young civil servants are overrepresented (29 per cent as opposed to 23 per cent in the Polish civil service). We assume a similar level of representativeness for the Latvian sample but have not been able to secure population-based data that would have allowed for a valid comparison against our sample data. For the analysis below we address potential biases by controlling for demographic variables such as sex, age and experience in public administration.

The survey primarily asked questions with regard to the implementation of civil service policy and the attitudes of officials towards principles of civil service management. A subset of questions directly addressed the experience of respondents with post-crisis civil service management. Answers were measured on the Likert scale, ranging from 1 (strongly disagree) to 5 (strongly agree). Respondents were given the option 'don't know' if they could not or did not want to answer a question. For the analysis 'don't know' responses were re-coded as 'neutral' responses. ${ }^{18}$

Ideally, we would be able to measure the motivation of officials by means of panel data that compares the pre- and post-crisis situation in the civil service in the two countries. Unfortunately, we do not have directly comparable data for such two points in time. In order to address this limitation, the survey included several questions that directly addressed the experience with civil service management since the onset of the global economic crisis. For instance, we asked 'The practice of promoting staff in my ministry has not changed since the beginning of the global financial crisis and its repercussions for my country', It should be noted that we asked for 'non-change' therefore assuming that civil service management practices might have persisted since the pre-crisis period. For the analysis we reversed the coding of the variable for ease of interpretation. Throughout the analysis in this article, a higher value therefore indicates more change in the respective area of human resource management.

Second, asking for change does of course not tell us 'what kind of change' nor 'what direction of change', We addressed this issue by asking a follow-up question in which respondents could specify what, according to them, had changed, for instance, in the practice of promoting staff. A large proportion of respondents completed the open questions and has provided rich insight into the perception of officials vis-à-vis post-crisis civil service reforms. Most answers were short but they would usually be unambiguous specifying 'salary cuts', 'bonus cuts', 'no recruitment of new staff', 'no more promotions', 'no more trainings', or in many cases simply 'no change',

The open answers have allowed us to interpret the Likert scale questions and to assume relatively confidently that 'change' is by and large synonymous with 'negative change', 'decline' or 'cuts', For each of the five areas of civil service management, we have been able to identify patterns that allow us to associate change with 'hiring freezes' in the case of recruitment policy, 'a growing number of dismissals' for dismissal policy, 'promotion freezes' for promotion policy, 'salary cuts' for salary management and a 'reduction of training opportunities' for training policy. These patterns apply to both countries. They simply differ in the extent to which respondents report change of this kind (see below, Table 1).

The survey also included one question that asked for the change in motivation of officials. The motivation question explicitly asked 'Officials in my ministry are as

\footnotetext{
18 The analysis below was also conducted without including 'don't know' responses. Substantively, the results are the same. It should be noted that the survey contains selective non-response, leaving up to 15 per cent of some of the variables missing.
} 
motivated to do their job as they were before the global financial crisis and its repercussions for my country.' Asking with regard to the departmental level rather than the individual level has the advantage that answers might be subject to less social desirability bias, as respondents might not have wanted to indicate openly that their own motivation level has declined since the onset of the crisis. ${ }^{19}$

For the question on the motivation of officials we did not ask an open follow-up question in the survey. We can therefore not rely on a second, open-ended survey response to ascertain that a change in motivation among ministerial officials is equivalent to a decrease in motivation. However, before and after conducting the survey we were able to conduct personal conversations with managing and nonmanaging civil servants in the two countries. ${ }^{20}$ They indicated that a negative connotation is plausible in that officials were - to varying degrees - disappointed, frustrated and over-worked after the austerity measures hit the civil service. ${ }^{21} \mathrm{We}$ therefore assume for the empirical analysis that change in motivation is equal to a decline in motivation after the crisis.

Table 1 lists the means and standard deviations for the dependent variable and the main independent variables. As mentioned earlier, a higher score indicates a higher degree of change, while a score of 1 indicates no change at all. For motivational change, the two-country mean is close to a neutral response of 3 . The higher mean for Latvia suggests that the austerity measures had a much greater impact on the motivation of public officials in Latvia than in Poland.

Table 1. Descriptive Statistics

\begin{tabular}{ccccccc}
\hline & Poland & & Latvia & \multicolumn{2}{c}{ Total } \\
\hline $\begin{array}{c}\text { Motivation } \\
\text { change }\end{array}$ & Mean & Std.Dev. & Mean & Std.Dev. & Mean & Std.Dev. \\
$\begin{array}{c}\text { Recruitment } \\
\text { change }\end{array}$ & 2.79 & 0.91 & 3.28 & 0.98 & 2.96 & 0.97 \\
$\begin{array}{c}\text { Promotions } \\
\text { change }\end{array}$ & 2.71 & 0.86 & 2.69 & 0.85 & 2.75 & 0.86 \\
$\begin{array}{c}\text { Dismissals } \\
\text { change }\end{array}$ & 2.71 & 0.77 & 2.74 & 0.83 & 2.72 & 0.80 \\
$\begin{array}{c}\text { Salaries } \\
\text { change }\end{array}$ & 2.65 & 1.05 & 3.31 & 0.99 & 2.88 & 1.08 \\
$\begin{array}{c}\text { Training } \\
\text { change }\end{array}$ & 2.76 & 0.82 & 3.54 & 0.97 & 3.04 & 0.96 \\
\hline
\end{tabular}

Table 1 also shows important differences with regard to the independent variables, in particular, the experience with post-crisis civil service management. The values for recruitment and promotion policy, for instance, do not differ much, and in both countries, they indicate similar developments. By contrast, in the areas of dismissals and, in particular, salary and training policy the differences between Latvia and Poland are larger. In these cases, the open answers echo the austerity measures outlined above. A large proportion of Latvian respondents simply answered, 'salary cut by 30 per cent', 'salary cut by 40 per cent', 'no more

\footnotetext{
${ }^{19}$ While the survey question provides a general indicator of the degree of motivation among ministerial staff and a first attempt to address the problem of post-crisis change in motivation, we are acutely aware that motivation is ideally measured by more than one item (Beulens/Van den Broeck 2007, Wright 2001).

${ }^{20}$ We did not conduct systematic interviews. However, the regular conversations with staff in the context of the preparation and implementation of the survey have given us valuable insights for the interpretation of the data.

${ }^{21}$ It should be recognised of course that for many there was also a sense of relief in that they could hold on to their job while unemployment rates rose.
} 
bonuses', 'no more training' etc. By contrast, for Polish respondent, a much larger proportion suggested 'no change' or merely 'no salary increase', 'salaries have been frozen' etc. In other words, the cutback measures are clearly reflected respondents' statements.

One of the major merits of our survey is that it captures how public officials appear to experience cutbacks in different ways. Indeed, it is likely that cutbacks in the area of civil service management are not uniformly implemented across public administration, as it is more than common that certain institutions and jobs are sheltered while others are earmarked for change (see Parrado 2010). Moreover, even if a much larger proportion of Latvian officials evidently 'complained' about salary cuts, the open survey responses indicated that there were considerable differences in the depth of the cuts, ranging from $5-50$ per cent. This clearly reflects the government's post-crisis policy, whereby senior managers were given discretion to allocate the salary cuts of the second stage of reforms in the summer of 2009.

For the assessment of our hypotheses, we include several control variables. First, we include basic demographic variables such as sex, age, experience in public administration and education in order to control for potential biases in our sample and to take into account the literature on work motivation in the public and private sector (for example, Buelens and Van den Broeck 2007). For sex we include a dummy variable for 'female', Both age and experience are measured in bands and dummy variables are included accordingly. With regard to the level of education it is worth mentioning that the survey distinguishes degrees that have been completed and degrees that are still in progress. For the analysis, we code finished and unfinished degrees in the same category (e.g. 'finished and unfinished PhD degree', which acts as the reference category below), as we consider participation in an MA programme to be closer in educational experience to the completion of an MA than to a completed BA programme.

Further, the rank of respondents is included, as managers with more responsibilities and control within an organisation are likely to be more motivated. They might also be more optimistic in their assessment of the motivational levels of their staff (Rainey 2001; Buelens and Van den Broeck 2007). We therefore include a dummy variable for 'manager' in our models.

Finally, we control for the country of origin and the ministry in which the official works. As outlined above, we expect that motivational change is greater in Latvia than in Poland due to the severity of the crisis and the scale of the subsequent austerity measures. Finally, we include a dummy variable for officials who work in finance and economics ministries. We expect that they remain more motivated after the crisis because they might be less affected by the cutbacks. Many of the austerity measures - outlined above - target social policy, while officials in finance and economic affairs are more likely to be sheltered from negative effects. Moreover, their status may even be elevated in that they might see themselves as the ones who solve the economic crisis.

\section{Results and discussion}

Table 2 presents the results of the analysis for the explanation of motivation among public officials. The Table consists of four models. Model 1 shows the impact of five human resource management practices on motivation without controlling for country and ministry context and without taking into account demographic confounders. Model 2 adds the country and the position of finance and economics ministries in order to take into account broad features of the work context.

Model 3 presents the main results of the linear regression analysis. It shows the five main variables together with the contextual and the demographic variables. Model 4 is primarily meant as a robustness check. It presents the results of a 
logistic regression analysis showing the odds that a change in motivation occurs. The presentation of the logistic regression analysis is limited to the model that includes the main variables and the control variables.

Looking at the results, model 3 shows that changes in recruitment, dismissal and training policy decrease motivation among public officials. The three variables are significant at the 1 per cent level and confirm the hypotheses that hiring freezes, staff cuts and a reduction of training opportunities reduce the motivation of ministerial staff. In relative terms, changes in the provision of training have the largest effect $(b=0.16, t=4.48, p<0.001)$. The magnitude of the effect of hiring freezes $(b=0.11, t=2.90, p<0.004)$ and staff cuts $(b=0.11, t=2.41, p<0.016)$ is slightly smaller.

Table 2. Change of motivation since the beginning of the global economic crisis

\begin{tabular}{|c|c|c|c|c|}
\hline & Model 1 & Model 2 & Model 3 & Model 4 \\
\hline & B & B & B & $\operatorname{Exp}(B)$ \\
\hline (Constant) & $1.604^{* * *}$ & $1.626^{\star * \star}$ & 0.506 & 0.434 \\
\hline Recruitment policy change & $0.094^{* * *}$ & $0.107^{* \star *}$ & $0.112^{* * *}$ & $1.254^{* *}$ \\
\hline Promotion policy change & 0.001 & -0.012 & -0.014 & 1.075 \\
\hline Dismissal policy change & $0.069^{* *}$ & $0.11^{* *}$ & $0.105^{\star * *}$ & $1.396^{* * *}$ \\
\hline Salary policy change & $0.094^{\star * \star}$ & 0.047 & 0.045 & 1.117 \\
\hline Training policy change & $0.206^{\star \star *}$ & $0.158^{\star * \star}$ & $0.155^{\star \star \star}$ & $1.251^{\star * *}$ \\
\hline Latvia & & $0.352^{* \star \star}$ & $0.301^{* * *}$ & $1.49^{* *}$ \\
\hline Finance ministries & & 0.061 & 0.042 & 0.958 \\
\hline Manager & & & 0.022 & 0.993 \\
\hline Female & & & -0.035 & 1.129 \\
\hline \multicolumn{5}{|l|}{ Age (ref. cat. 'under 30 years') } \\
\hline 30 to 40 years & & & $-0.142^{*}$ & 0.841 \\
\hline 40 to 50 years & & & -0.094 & 0.922 \\
\hline $\begin{array}{c}50 \text { years and older } \\
\text { Experience in public admin (ref.cat. ' }<1 \\
\text { year') }\end{array}$ & & & $-0.345^{\star \star \star}$ & $-0.643^{*}$ \\
\hline 1 to 4 years & & & -0.069 & $0.207^{\star \star *}$ \\
\hline 5 to 10 years & & & 0.071 & $0.262^{* \star *}$ \\
\hline 11 and more years & & & 0.048 & $0.225^{\star * *}$ \\
\hline \multicolumn{5}{|l|}{ Education (ref.cat. 'PhD degree') } \\
\hline MA degree & & & 0.125 & 1.349 \\
\hline BA degree & & & 0.123 & 1.405 \\
\hline No higher education & & & 0.184 & 1.781 \\
\hline R Square & 0.099 & 0.125 & 0.133 & \\
\hline Nagelkerke R Square & & & & 0.139 \\
\hline
\end{tabular}

By far the largest significant coefficient belongs to the country dummy variable and hence the differences between Latvia and Poland $(b=0.30, t=4.06, p<0.001)$. It suggests that even if the five human resource management variables are likely to absorb a great deal of the differences in officials' experience with cutback measures, a range of wider country-level factors must be taken into account when seeking to understand differential change in motivation among officials. By contrast, employment in finance and economics ministries does not have an effect on motivation. Country differences and differences in the way cutbacks are 
experienced appears to be more relevant for motivational change than the ministerial work context within countries.

Model 4, which presents the results of the logistic regression analysis, confirms the significant effect of changes in recruitment, dismissals and training policy on motivation. The odds of observing a change in motivation are 39.6 per cent higher for officials who have experienced major staff cuts in their department. For officials who have experienced hiring freezes and a cut in training provision the odds of perceiving a change in motivation are slightly lower at 25 per cent.

Model 4 also confirms the major effect of the country context and hence the scale of the cutback measures. For Latvian officials the odds of having experienced motivational change in their ministry are 49 per cent higher than for Polish officials. Model 4 indicates that officials from finance and economics ministry do not differ in their perception of motivation after the implementation of the cutbacks.

Table 2 further suggests that salary cuts and promotion freezes are not associated with a change in motivation. The effect of changes in salary policy shrinks and loses significance when the country and ministerial contexts are included in the analysis (compare models 1 and 2). Promotion freezes, by contrast, do not have any significant effect on motivational change among public officials. The structure of the civil service systems in Poland and Latvia is likely to be responsible for the irrelevance of promotion freezes. Both countries operate a position-based system that does not provide much room for promotions (Meyer-Sahling 2009; Demmke and Moilanen 2010). Career advancement tends to require participation in several rounds of competition procedures rather than any prospect of automatic promotion. The relative importance of changes in recruitment policy, which refers to all levels in the hierarchy rather than just the entry level, captures this aspect of the civil service systems in the two countries very well.

The secondary role of salary policy might be more surprising, as conventional wisdom would initially point to the detrimental effect of salary cuts for the motivation of employees. However, research that compares the motivational basis of private and public sector employees tends to argue that public sector employees are less motivated by monetary rewards (Boyne 2002; Beulens and Van den Broeck 2007). They tend to value job security, a supportive work environment and a better work-life balance more than their private sector peers (Chen and Hsieh 2015). To be sure, the lower importance of mechanisms of extrinsic motivation such as salaries and promotions also resonates closely with the research on 'public service motivation' which stress that public officials are motivated by working for a 'good cause' and not just for monetary reward (for a recent review, see Perry et al 2010).

The importance of training, dismissal and recruitment policy relative to salary and promotion policy resonates closely with this line of argumentation. Training budgets tend to be one of the first items that are cut when savings have to be made (Demmke 2016). Yet the analysis supports the view that public officials value the opportunity to develop their skills and competences to better perform their job. Both recruitment freezes and staff cuts also relate closely to the quality of the work environment and hence the working conditions. They inevitably increase the workload of officials and, in addition, one should not underestimate the negative impact on staff morale in the departments following staff cuts and re-organisations.

Model 3 and 4 also show the role of demographic factors on motivation among officials in Latvia and Poland. Model 3 and 4 suggest that older officials are less likely to perceive motivational change within their institution. Moreover, according to model 4 officials with more years of experience are less likely to perceive a change of motivation. The results suggest that the older generation has responded less negatively to cutbacks in the civil service. Older as well as more experienced officials have fewer job opportunities outside the administration and they are more likely to seek (to continue) a long-term career in the civil service given their 
experience so far. They might therefore be more willing to bear the consequences of the cutbacks and they appear to be more likely to accept the need to get on with the job even under adverse conditions.

\section{Conclusion}

This article has examined the impact of cutbacks in the area of civil service management on the motivation of public officials in Latvia and Poland. Based on a survey of ministerial officials, it has shown that Latvian officials are more likely to perceive changes in motivation than their peers from Poland. The differences clearly reflect the scale of the austerity-driven cutbacks in Latvia in comparison to Poland.

With regard to different areas of civil service management, the article has shown that changes in recruitment, dismissals and training policy undermine the motivation of staff in central government ministries. In the context of cutback management, these changes tend to refer to hiring freezes, staff cuts and a reduction in the provision of training. By contrast, salary cuts and promotion freezes did not negatively affect the motivation of public officials.

The results suggest that public officials in Latvia and Poland are relatively less motivated by monetary rewards and prospects of career advancement. This finding resonates with research on employee motivation in the private and public sector. Extrinsic motivation, which focuses on material incentives, tends to be less relevant for public sector employees (Boyne 2002; Buelens and Van den Broeck 2007, Chen and Hsieh 2015). By contrast, recruitment freezes, staff cuts and cuts in training provision are more closely related to workload considerations, the quality of the working conditions and interest in self-development. These factors tend to be valued highly by public sector employees. The findings of this article suggest that these differences also apply in the context of austerity programmes.

The article relied on the analysis of post-crisis survey data rather than a comparison of data from before and after the crisis hit the two Central and Eastern European countries. Inevitably there is some uncertainty regarding the findings. Moreover, for the purpose the analysis we had to rely on comparably simple measures of motivation and motivational change. However, the differences between the two countries and the perception of austerity-driven civil service reforms as reported in quantitative and qualitative answers are reasonably plausible and provide a first glimpse at the trade-offs that governments face when seeking to implement austerity-oriented reforms.

Cutbacks in the area of civil service management have been and are likely to remain key instruments for governments to reduce costs and increase efficiency in public administration during times of crisis. This article has shown that the implementation of these kinds of measures entails additional, hidden costs for government, in that they appear to undermine the motivation of public officials. However, the costs of reform depend on the scale of the cutbacks and they are not uniform across areas of civil service management, giving governments some discretion over the choice of instruments. It remains to be seen to what extent the results for Latvia and Poland hold up to the inclusion of more countries and a longer-term comparison over time.

\section{References}

Armingeon, Klaus (2012) 'The politics of fiscal responses to the crisis of 20082009', Governance, 25(4): 543-565.

Bida, A, (2009) 'Problemy motywacji zatrudnienia w służbie cywilnej (Problems with civil servants job motivation)' in W Mikułowski and A Jezierska (eds) Wyzwania rozwoju zasobów ludzkich administracji publicznej w dobie kryzysu ekonomicznego 
(Challenges of public administration human resources development at the time of economic crisis, Conference proceedings, Warszawa (Warsaw), 10-11 December 2009, pp. 109 - 113.

Bideleux, Robert (2011) 'Contrasting responses to the international economic crisis of 2008-10 in the $11 \mathrm{CIS}$ countries and in the 10 post-communist EU member countries', Journal of Communist Studies and Transition Politics 27(3-4): 338-363.

Boyne, George A. (2002) 'Public and private management: what's the difference?', Journal of Management Studie, 39(1): 97-122.

Brans, Marleen and B. Guy Peters (eds) (2012) Rewards for High Public Office in Europe and North America. London: Routledge.

Brewer, Gene A. and Gene A. Jr Brewer (2011) 'Parsing public/private differences in work motivation and performance: an experimental study', Journal of Public Administration Research and Theor, 21(2): 347-362.

Buelens, Mark and Herman Van den Broeck (2007) 'An analysis of differences in work motivation between public and private sector organizations', Public Administration Review, 67(1): 65-74.

Chen, Chung-An and Chih-Wei Hsieh (2015) 'Does pursuing external incentives compromise public service motivation? Comparing the effects of job security and high pay', Public Management Review, 17(8):1190-1213.

Dahlström, Carl and Victor Lapuente (2010) 'Explaining cross-country differences in performance-related pay in the public sector', Journal of Public Administration Research and Theory, 20, pp. 577-600.

Darzinaa, Lidija (2009) 'Nosaka robežsummas atalgojuma samazināšanai valsts pārvaldē (Ceiling for salary cuts in public administration has been defined)', Latvijas Vēstnesis, 01.07.2009. Available at http://www.Ivportals.Iv/print.php?id=194174.

Demmke, Christoph (2016) 'Effects of budgetary constraints on HR reforms in central public administrations and the importance of institutional context', International Journal of Public Administration, early online 7 Nov 2016.

Demmke, Christoph and Timo Moilanen (2010) Civil services in the EU of 27: Reform Outcomes and the Future of the Civil service, Frankfurt: Peter Lang.

Gazeta Prawna (2011) Służba cywilna: Niewielu kandydatów do awansu w urzędach (Civil service: not many candidates to be nominated), Gazeta Prawna online version. Available at http://praca.gazetaprawna.pl/artykuly/507642,sluzba_cywilna_niewielu_kandydato w_do_awansu_w_urzedach.html.

Gazeta Prawna (2013a) 'Podwyżek dla urzędników nie ma. I nie będzie (No salary increases for public officials)', Gazeta Prawna online version. Available at http://serwisy.gazetaprawna.pl/praca-i-

kariera/artykuly/712547,podwyzek_dla_urzednikow_nie_ma_i_nie_bedzie.html.

Gazeta Prawna (2013b) 'Rząd utrudnia awans urzędnikom. Kto może liczyć na wyższą pensję i stabilną pracę? (Government makes promotions of public officials more difficult. Who can expect higher salary and job stability?)', Gazeta Prawna online version. Available at http://serwisy.gazetaprawna.pl/praca-ikariera/artykuly/708324,rzad_utrudnia_awans_urzednikom_kto_moze_liczyc_na_w yzsza_pensje_i_stabilna_prace.html.

Government of Latvia (2008) Par Ministru kabineta 2008.gada 9.decembra sēdes protokollēmumu (prot. Nr.89 1.§) "Likumprojekts "Grozijumi likumā "Par valsts budžetu 2009.gadam"', un Latvijas ekonomiskās stabilizācijas un izaugsmes atjaunošanas programma" (On the decision of the Cabinet of Ministers made during the meeting on 9 December 2008 - "Amendment to the state budget law for 
2009" and "Programme of Economic Stabilisation and Growth"). Available at http://www.mk.gov.lv/lv/mk/tap/?pid=40102497\&mode=mk\&date=2008-12-09

Guest, David E. (1997) 'Human resource management and performance: a review and research agenda', International Journal of Human Resource Management 8(3): 263- 276.

Guthrie, James P (2008) 'Remuneration: Pay effects at work, in Peter Boxall', John Purcell and Patrick Wright (eds), The Oxford Handbook of Human Resource Management, Oxford: Oxford University Press, pp.344-363

Hondeghem, Annie and James L. Perry (2009) 'EGPA symposium on public service motivation and performance: introduction', International Review of Administrative Sciences 75(1), pp. 5-9.

Huselid, Mark A. (1995) 'The impact of human resource management practices on turnover, productivity, and corporate financial performance', Academy of Management Journal 38(3): 635-672.

Kelly, Josie and Anneliese Dodds (2012) 'Public administration in an age of austerity: the future of the discipline', Public Policy and Administration 27(3):199211.

Kickert, Walter, and Tiina Randma-Liiv (2016) 'The politics of cutback management in thirteen European countries: Statistical evidence on causes and effects', Public Management Review, 19(2):175-193.

Kickert, Walter, Tiina Randma-Liiv and Riin Savi (2015) 'Politics of fiscal consolidation in Europe: A comparative analysis', International Review of Administrative Sciences 81(3): 562-584.

Lepak, David P. Hui Liao, Yunhyun Chung and Erika E. Harden (2006) 'A conceptual review of human resource management systems in strategic human resource management research', Research in Personnel and Human Resources Management 25, 217-271.

Leslie, Keith and Adam Canwell (2010) 'Leadership at all levels: leading public sector organisations in an age of austerity', European Management Journal, 28(4): $297-305$.

Leta, (2009) 'Valdība apņemas ierēdņu skaitu samazināt līdz $8 \%$ no iedzīvotāju skaita (The government decided to cut employees in public administration by $8 \%$ of total number)', September 15, 2009. Available at http://www.tvnet.Iv/zinas/latvija/195494-

valdiba_apnemas_ierednu_skaitu_samazinat_lidz_8_no_iedzivotaju_skaita.

Lodge, David and Marta Rodríguez-Vives (2013) 'How long can austerity persist? The factors that sustain fiscal consolidations', European Journal of Government and Economics 2(1): 5-24.

Lodge, Martin and Christopher Hood (2012) 'Into an age of multiple austerities? Public management and public service bargains across OECD countries', Governance 25(1):79-101.

Lodge, Martin and Kai Wegrich (eds) (2012) Executive Politics in Times of Crisis, Basingstoke: Palgrave.

Marsden, David (2010) 'The paradox of performance-related pay systems: why do we keep adopting them in the face of evidence that they fail to motivate?', in Christopher Hood, Helen Margetts and Perri (eds) Paradoxes of Modernization: Unintended Consequences of Public Policy Reforms, Oxford: OUP, pp. 185-202.

Memorandum (2009) Memorandum of Understanding between the European community and the Republic of Latvia, 29.01.2009. Available at www.ec.europa.eu/latvija/documents/pievienotie_faili/29.01.09.mou.doc 
Metsma, Merilin (2014) 'The impact of cutback management on civil service training: The case of Estonia', Administrative Culture 15(1):58-79.

Meyer-Sahling, Jan-Hinrik (2009) The Sustainability of Civil Service Reform in Central and Eastern Europe Five Years after Accession. SIGMA Paper Nr 44. Paris: OECD Publications.

Meyer-Sahling, Jan-Hinrik and Kim Sass Mikkelsen (2016) 'Civil service laws, merit, politicization, and corruption: The perspective of public officials from five East European countries', Public Administration, 94(4):1105-1123.

Ministry of Finance (2012) Finanšu ministrija. Dati par ekonomikas izaugsmi 2011.gadā turpina iepriecināt (The Ministry of Finance of The Republic of Latvia. Data on economic growth in 2011 continues to please). Available at 2012 http://www.fm.gov.lv/?lat/aktualitates/jaunumi/50908.

OECD (2012) Public sector compensation in times of austerity, Paris:OECD Publications.

Parrado, Salvador (2010) Sustainability of Human Resources in Central Public Administration in the EU Member States, Brussels: European Public Administration Network.

Perry, James L. and Lois R. Wise (1990) 'The motivational bases of public service, Public Administration Review 50(3):367-373.

Perry, James L., Annie Hondeghem and Lois R. Wise (2010) 'Revisiting the motivational basis of public service: twenty years of research and an agenda for the future', Public Administration Review 70(5): 681-690.

Peters, B. Guy, Jon Pierre and Tiina Randma-Liiv (2011) Global financial crisis, public administration and governance: do new problems require new solutions?, Public Organization Review 11(1):13-27.

Potter, Michael (2012) 'Still learning to speak and still not being heard: public administration and the latest financial crisis', Administration \& Society 44(3):367373.

Rae, G, (2013) 'Avoiding the economic crisis: pragmatic liberalism and divisions over economic policy in Poland', Europe-Asia Studies 64(3):411-425.

Rainey, Hal G. (2001) 'Work motivation', in R.T. Golembiewski (Ed.) Handbook of Organisational Behaviour, $2^{\text {nd }}$ Edition, , New York: Marcel Dekker, pp. $19-42$.

Raudla, Ringa, Riin Savi and Tiina Randma-Liiv (2015) 'Cutback management literature in the 1970s and 1980s: Taking stock, International Review of Administrative Sciences 81(3): 433 - 456.

Savi, Riin and Tiina Randma-Liiv (2015) 'Decision-making in time of crisis: Cutback management in Estonia' International Review of Administrative Sciences 81(3): 479-497.

UNDP (2010) Challenges for Public Sector Human Resources Management in the Recent Economic Downturn, Bratislava: Regional Centre for Public Administration Reform of UNDP.

Wright, Bradley E. (2001) 'Public-sector work motivation: a review of the current literature and a revised conceptual model', Journal of Public Administration Research and Theory 11(4):559-586.

Wright, Patrick M, and Wendy R. Boswell (2002) 'Desegregating HRM: a review and synthesis of micro and macro human resource management research', Journal of Management 28(3):247-276.

Zieliński, Wojciech (2009) 'Modernizacja zarządzania zasobami ludzkimi w administracji publicznej (Modernisation of human resources management in public 
administration)', in W. Mikułowski and A. Jezierska (eds) Wyzwania rozwoju zasobów ludzkich administracji publicznej $w$ dobie kryzysu ekonomicznego (Challenges of public administration human resources development at the time of economic crisis), Conference proceedings, Warszawa (Warsaw), 10-11 December 2009, pp. 99-106. 